\title{
The Study of P53immunoexpression In Carcinoma Cervix
}

\author{
Dr.P.Aruna ${ }^{1}$, Dr. L. Lakshmana rao ${ }^{2}$
}

'Assistant Professor, Dept of Pathology, JIPMER Karaikal, Puducherry Union Territory.

${ }^{2}$ Formerly Professor and Head of the Department of Pathology, Rajah Muthiah Medical College, Chidambaram,Tamilnadu.

\section{ABSTRACT}

Background : Worldwide cervical carcinoma is responsible for about $5 \%$ of all cancer deaths in women. Loss of $\mathrm{p}^{53}$ functions is believed to play an important role in the pathogenesis of carcinomas of the uterine cervix. Mutation of the $\mathrm{p}^{53}$ tumor suppressor gene is the most frequent genetic event described thus far in human cancer. Normal $\mathrm{p}^{53}$ protein has a very short half life and thus the protein level is too low to be identified immunohistochemically. In contrast most mutant $\mathrm{p}^{53}$ proteins have a longer half life and are easily detected by immunohistochemical methods.

Aim: The aim of the present study is to examine the over expression of $\mathrm{p}^{53}$ protein in different tumor types of carcinoma cervix.

Materials and methods: This is a retrospective study carried out in the 285 paraffin blocks from the cases of carcinoma cervix in the department of Pathology, Rajah Muthiah Medical College, Chidambaram. Immunohistochemical study using Dextran polymer conjugate-Two step visualization system is used besides H\&E staining.

Results: Out of 285 cervical carcinoma biopsies 50 cases were randomly selected and subjected to immunohistochemical analysis for $\mathrm{p}^{53}$ protein.

$p^{53}$ expression was found to be positive in 42 cases $(84 \%)$, which include:

- 39 squamous cell carcinoma

- 1 adenocarcinoma

- I adenosquamous carcinoma

- 1 small cell carcinoma

Conclusion: Loss of 53 function is having a key role in squamous cell carcinoma of cervix.

Key words: Carcinoma cervix, p53 protein, immunohistochemistry.

\section{INTRODUCTION:}

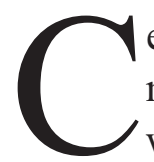
ervical cancer is the second leading malignant neoplasm affecting women worldwide. It continues to be a public health problem particularly in developing countries and among socially disadvantaged population ${ }^{1}$ Worldwide cervical carcinoma is responsible for about $5 \%$ of all cancer deaths in women. ${ }^{2}$

Loss of $\mathrm{p}^{53}$ function is believed to play an important role in the pathogenesis of carcinomas of the uterine cervix. Mutation of the $\mathrm{p}^{53}$ tumor suppressor gene is the most frequent genetic event described thus far in human cancer. ${ }^{3}$

\section{$p^{53}$ Guardian of the Genome}

The $\mathrm{P}^{53}$ gene is located on chromosome $17 \mathrm{p} 13.1$ and it is the most common target for genetic alteration in human tumors. The fact that $\mathrm{p}^{53}$ mutations are common in a variety of human 
tumors suggest that the $\mathrm{p}^{53}$ protein functions as a critical gatekeeper against the formation of cancer, indeed it is evident that $\mathrm{p}^{53}$ protein acts as a "molecular policeman". The $\mathrm{p}^{53}$ protein is a DNAbinding protein localized to the nucleus; when called into action, it functions primarily by controlling the transcription of several other genes.

Mutation of the $\mathrm{p}^{53}$ tumor suppressor gene is the most frequent genetic event described thus far in human cancer

\section{Role of p53 in cervical carcinogenesis ${ }^{5}$}

Loss of $\mathrm{p}^{53}$ functions is believed to play an important role in the pathogenesis of carcinomas of the uterine cervix.

The major functional activities of the $\mathrm{p}^{53}$ protein are cell-cycle arrest and initiation of apoptosis in response to DNA damage. $\mathrm{p}^{53}$ is called in to apply emergency brakes when DNA is damaged by irradiation, UV light or mutagenic chemicals and also in response to changes in cellular redox potential, hypoxia, senescence and other stress conditions that may not directly damage DNA.

Normally cells with wild type $\mathrm{p}^{53}$ are able to delay progression from the G1 to the $\mathrm{S}$ phase of the cell cycle while abnormal DNA is repaired. Cells with the inactivated, stabilized or mutant $\mathrm{p}^{53}$ protein cannot, and thus the replication of abnormal DNA is not prevented. ${ }^{3}$

Once activated $\mathrm{p}^{53}$ can either induce cell growth arrest or apoptosis. The mechanism of $\mathrm{p}^{53}$ activation is crucial for its function as a tumour suppressor and understanding this mechanism may indicate new approaches for anti-cancer therapy and it is identified that the E7 gene of human papilloma virus is the survival factor for human cervical cancer cells (grown in cell culture).

Normal $\mathrm{p}^{53}$ protein has a very short halflife and thus the protein level is too low to be identified immunohistochemically. In contrast most mutant $\mathrm{p}^{53}$ proteins have a longer half life and are easily detected by immunohistochemical methods. ${ }^{4}$

\section{AIM:}

The aim of the present study is to examine the over expression of $\mathrm{p}^{53}$ protein in different tumor types of carcinoma cervix.

\section{MATERIALS AND METHODS:}

This retrospective study included 285 paraffin blocks from the biopsies diagnosed as carcinoma cervix on H\&E stained sections in the Department of Pathology, Rajah Muthiah Medical CollegeChidambaram, for a period of 5 years. The study was conducted after obtaining a human ethical committee clearance from the institution.

The biopsy material included cervical punch biopsies, endocervical curettings and hysterectomy specimens. 50 blocks were selected randomly

$5-\mu \mathrm{m}$ thick sections from each paraffin block were subjected to immunohistochemical studies using Dextran polymer conjugate-Two step visualization system, besides H\&E staining.

\section{Dextran polymer conjugate-two step visualisation system:}

This is an indirect system based on the dextran technology employed in the EPOS (Enhanced polymer one-step staining ) labeling system. The primary antibody in the EPOS model is replaced with a secondary antibody, available in either antimouse or anti-rabbit format it offers great sensitivity than the traditional indirect system. It is less time consuming than the three-stage avidinbiotin systems and does not react with endogenous biotin.

a) The sections were dewaxed in xylene.

b) Deparaffinized sections were treated with $0.3 \%$ Hydrogen peroxide in Methanol for 30 minutes to block endogenous peroxidase. 
c) The sections were incubated for 20 minutes with normal serum from the species in which the secondary antibody was made.This was done to eliminate non specific staining.

d) Excess normal serum was blotted from the slides and incubated with anti-p ${ }^{53}$ mouse monoclonal antibody, DO-7 from tissue culture supernatant diluted in PBS (phosphate buffered saline) at PH 7.6 containing 1\% BSA (biotin labeled secondary antibody) and $0.09 \%$ sodium azide.

e) Incubated at room temperature for $2 \mathrm{hrs}$.

f) Sections are cleared in xylol and mounted with DPX (dextrene polysterene xylene).

g) Positive control for this antibody is breast carcinoma tissue. Negative controls included replacement of polyclonal primary antiserum with rabbit serum diluted 1:500 whereas negative controls for the monoclonal antibody were performed using mouse myeloma protein of the same subclass and concentration as the monoclonal antibody. All controls gave satisfactory results.
The results were compared with the reports of other workers.

\section{OBSERVATION:}

\section{$p^{53}$ Immuno expression:}

Out of 285 cases of carcinoma cervix, $\mathrm{p}^{53}$ protein expression was assessed using standard immunohistochemical technique in 50 randomly selected cases. 39 cases of squamous cell carcinoma out of 47 cases $(82.9 \%)$ and one each of adenocarcinoma, adeno squamous carcinoma and small cell carcinoma were positive for $\mathrm{p}^{53}$ immuno expression. [table 1]

\section{Table 1. Carcinoma cervix $-p^{53}$ immuno expression}

\begin{tabular}{|c|l|cc|}
\hline S.No. & \multicolumn{1}{|c|}{ Tumor type } & Number of cases & p53 expression(+VE) \\
\hline 1. & Squamous cell carcinoma & 47 & $39(82.9 \%)$ \\
\hline 2. & Adeno carcinoma & 1 & $1(100 \%)$ \\
\hline 3. & Adeno squamous carcinoma & 1 & $1(100 \%)$ \\
\hline 4. & Small cell carcinoma & 1 & $1(100 \%)$ \\
\hline & Total & $\mathbf{5 0}$ & $\mathbf{4 2 ( 8 4 \% )}$ \\
\hline
\end{tabular}

Tumors in which there was nuclear positivity in at least $10 \%$ of the neoplastic cells were regarded as positive. Those tumors with only focal or no nuclear staining were regarded as negative. [Fig.1 to Fig.5]

Fig 1. Large Cell Keratinizing Squamous cell Carcinoma cervix Staining of p53 is seen in the nuclei (magnification-200x, 400×)
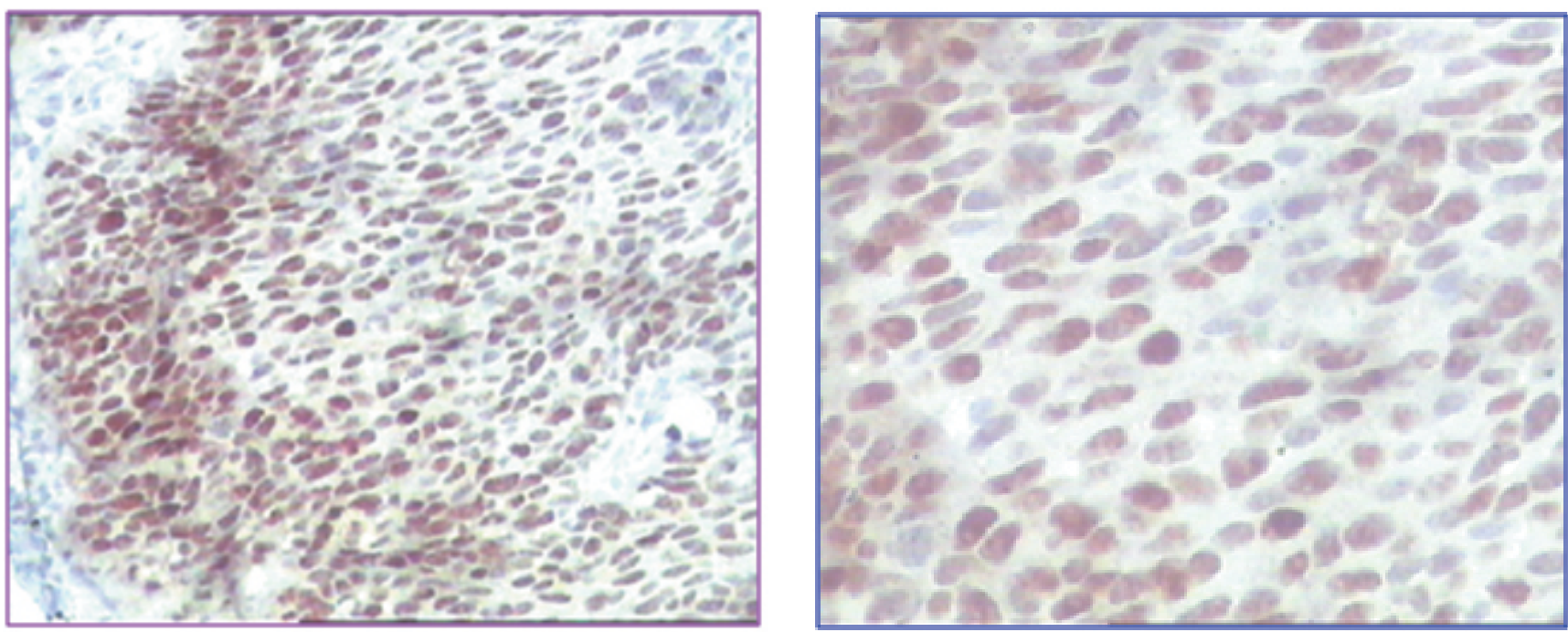
Fig 2. Large cell Nonkeratinizing Squamous cell Carcinoma cervix Staining of p53 is seen in the nuclei (magnification $200 x, 400 \times$ )
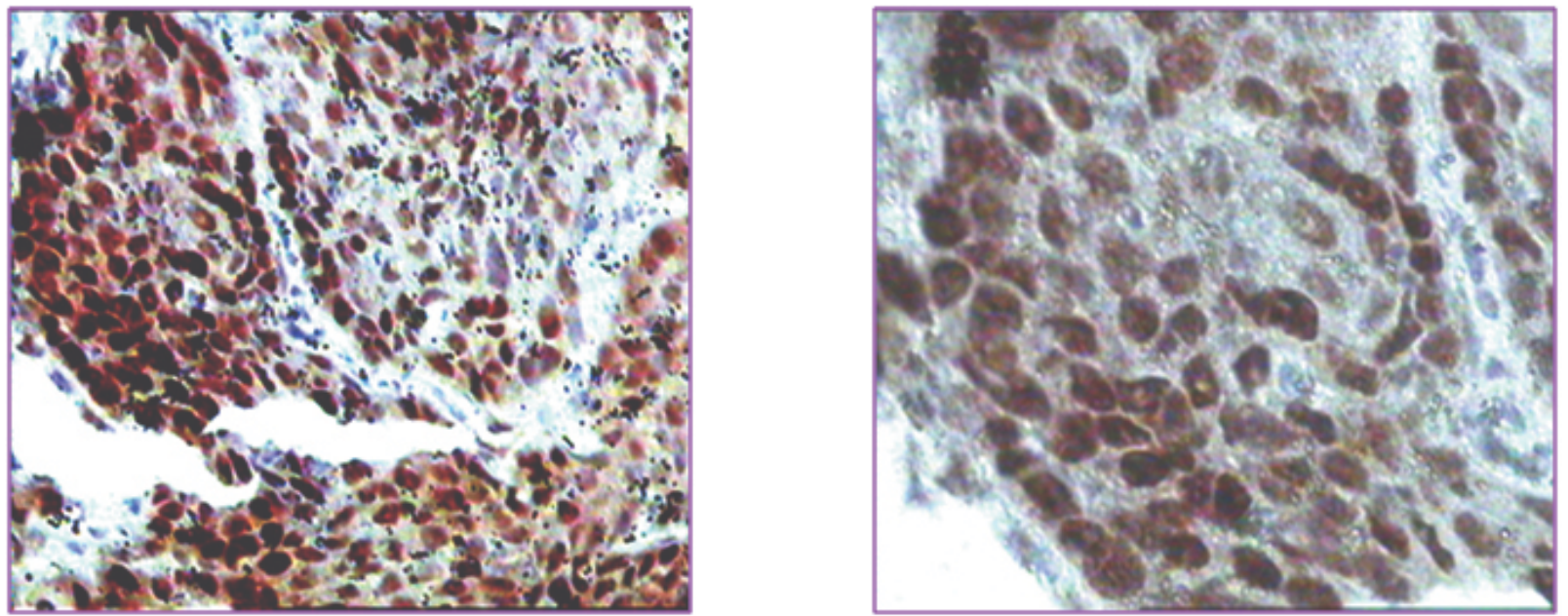

Fig 3. Adenocarcinoma cervix Staining of p53 is seen in the nuclei (magnification100x, 200×)
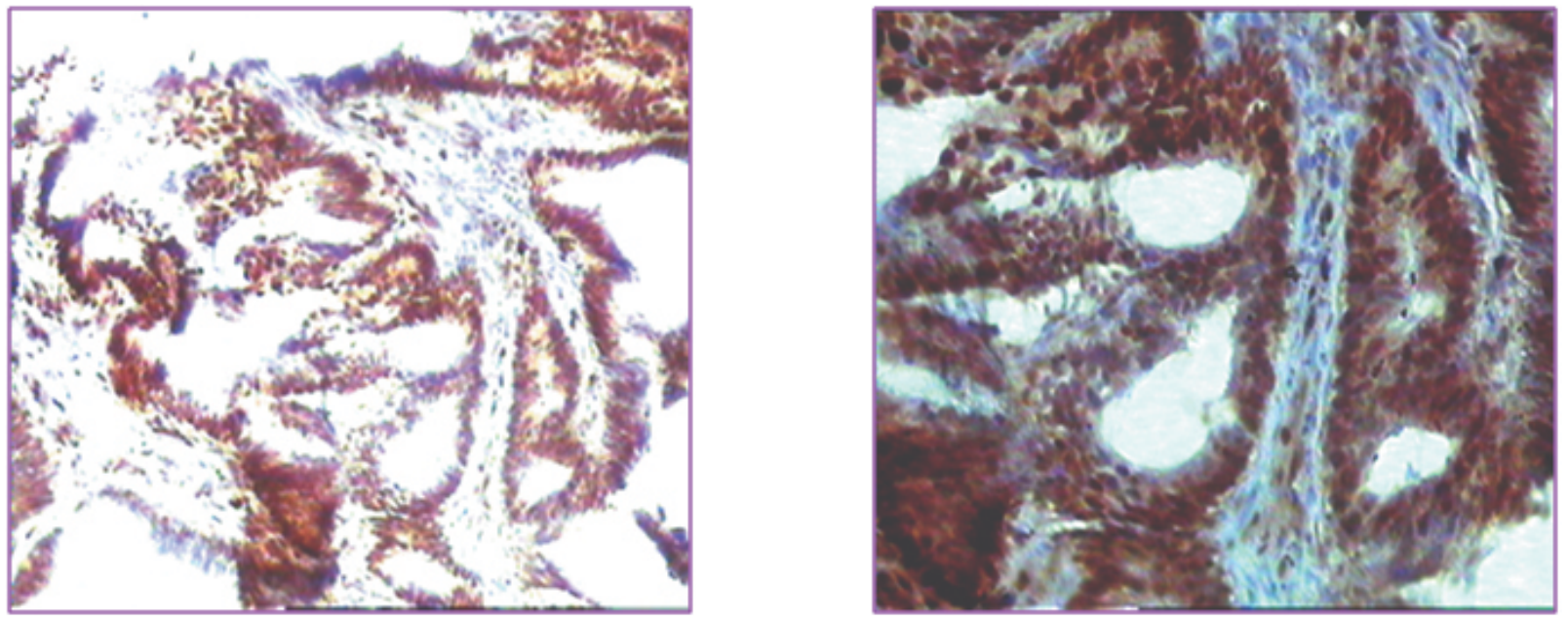

Fig 4. Adenosquamous carcinoma cervix Staining of p53 is seen in the nuclei (magnification100x, 200×)
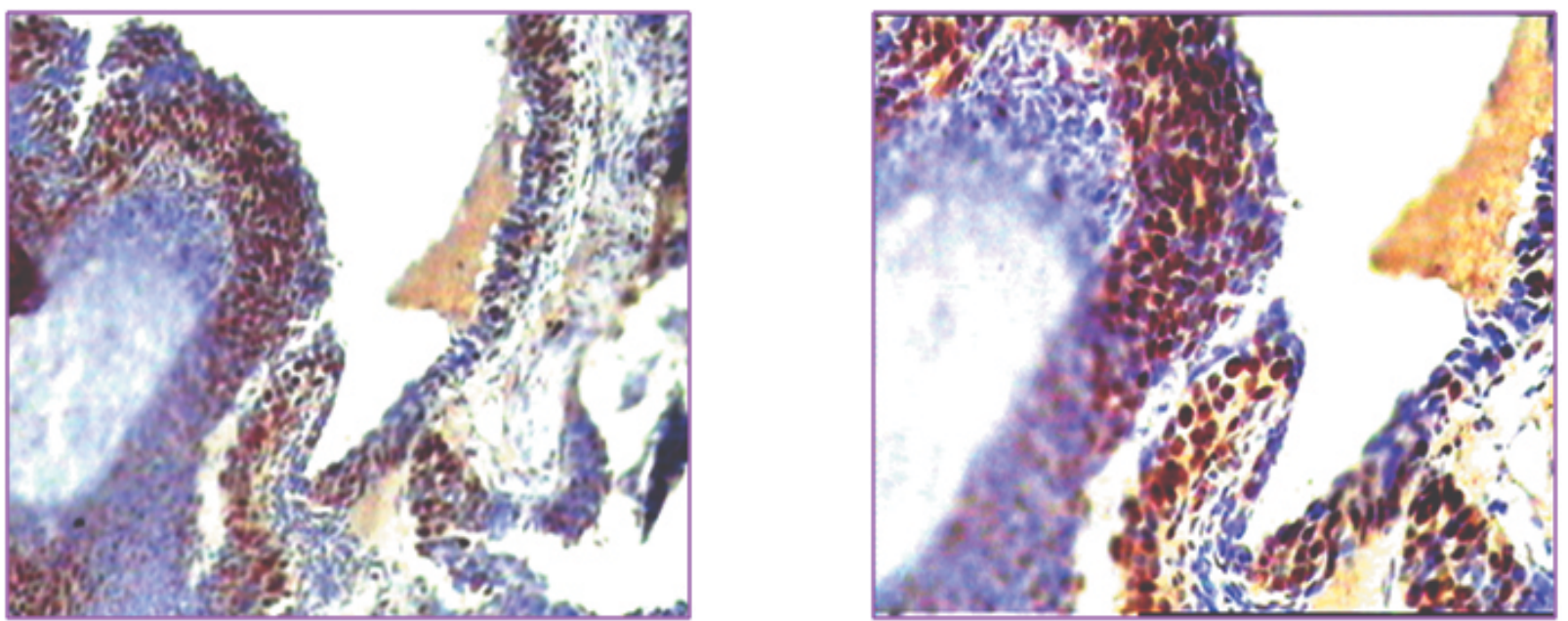


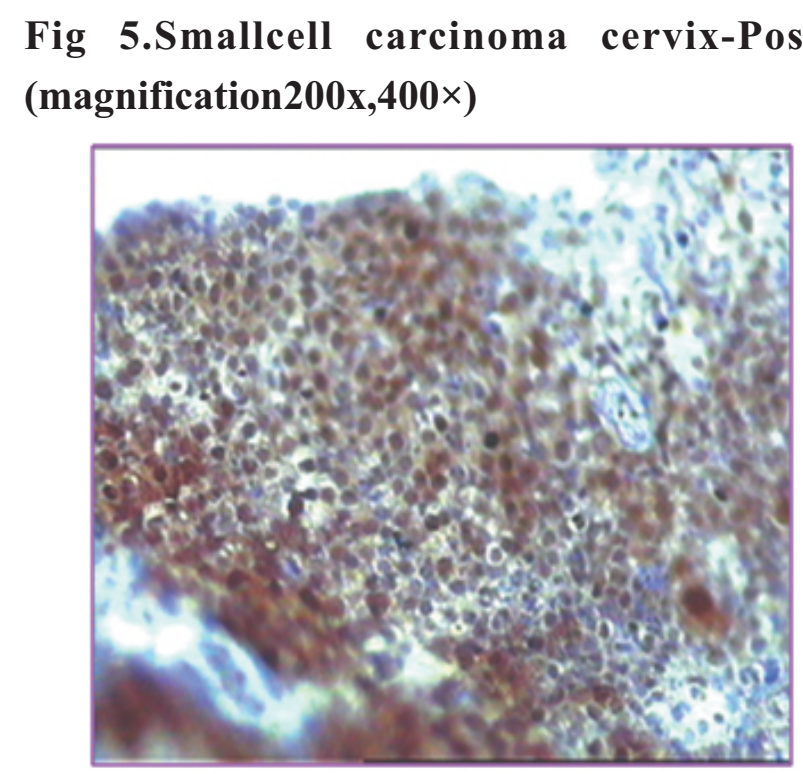

\section{DISCUSSION:}

Immunoreactivity for the $\mathrm{p}^{53}$ protein is commonly found in many different human malignancies, $\mathrm{p}^{53}$ point mutations have been demonstrated in human cervical carcinoma cell lines.

Bosari et al (1993)6 studied $\mathrm{p}^{53}$ immunoreactivity in 92 lesions of the uterine cervix, including 44 cases of chronic cervicitis, 29 squamous intra epithelial lesions and 19 invasive carcinomas, $\mathrm{p}^{53}$ immunoreactivity was demonstrated in 74 percent of invasive carcinoma

Helland A et al (1993) ${ }^{7}$ conducted a study on genetic alterations of the $\mathrm{Tp}^{53}$ gene, $\mathrm{p}^{53}$ protein expression and HPV infection in Primary cervical carcinomas, 92 patients were investigated for $\mathrm{p}^{53}$ immuno expression. Over expression of the $\mathrm{p}^{53}$ protein was found in 55\% (51/92) of the tumors.

Cooper K et al $(1993)^{8}$ conducted a study on 30 fresh cervical biopsies. ${ }^{22}$ were HPV positive cervical carcinomas including one adenocarcinoma. 19 (86\%) showed expression of $\mathrm{p}^{53}$ protein.
Staining of p53 is seen in the nuclei

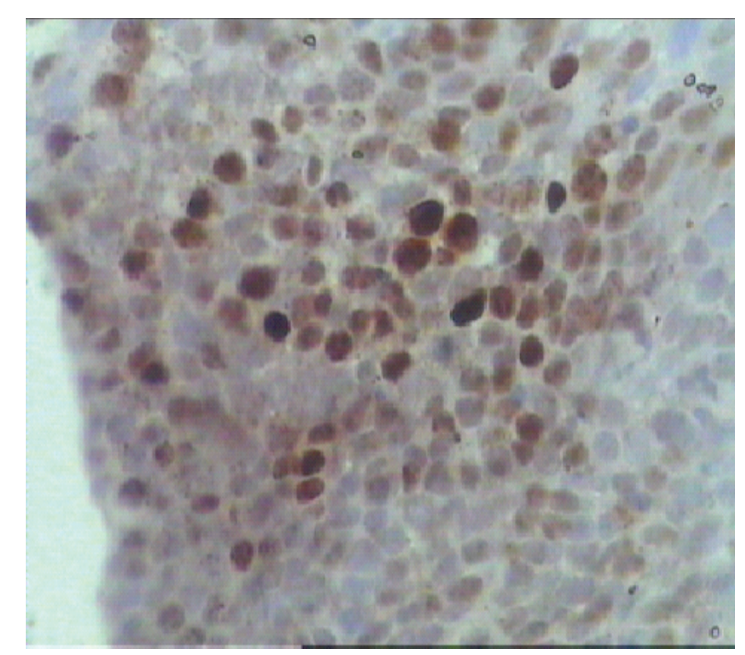

Of the eight HPV-negative squamous cell carcinoma, four showed an even distribution of $\mathrm{p}^{53}$ immunoreactivity, whilst in the other four tumours no $\mathrm{p}^{53}$ was detectable.

Holm R et al (1993) ${ }^{9}$ reported $\mathrm{p}^{53}$ Protein positivity in 62 percent of invasive adenocarcinomas and 7 percent of Squamous cell carcinomas in situ among two hundred and thirty-eight cervical lesions. No staining was found in adenocarcinoma in situ, dysplastic tissue, condyloma and normal tissue.

The results of the study indicate that altered expression of $\mathrm{p}^{53}$ protein may be involved in the progression of cervical carcinomas,

Hunt \& Hale (1996) ${ }^{3}$ conducted a study to assess the over expression of the tumor suppressor gene product $\mathrm{p}^{53}$ in the three main subtypes of carcinoma of the uterine cervix.

Eighty two cases of FIGO stage IB/IIA Uterine cervical carcinoma were studied retrospectively, $\mathrm{p}^{53}$ gene product was over expressed in $17.1 \%$ (14/82) of all carcinoma and also in areas of cervical intraepithelial neoplasia grade III adjacent to invasive squamous carcinoma. 
Howayda ABD EL ALL ${ }^{10}$, Annie RYE \& Peierre Duvillard (1999) Studied the $\mathrm{p}^{53}$ immunohistochemical expression of Egyptian cervical carcinoma in an attempt to evaluate its prognostic significance. 38 invasive carcinoma (31 Squamous cell carcinoma and 7 adenocarcinoma ranging from stage $1 \mathrm{~B}$ to IVB) were stained with the monoclonal antibody anti $\mathrm{p}^{53}$. Nuclear $\mathrm{p}^{53}$ reactivity was detected in all carcinomas. $\mathrm{p}^{53}$ expression was more pronounced in early clinical stages and in adenocarcinoma compared to squamous cell carcinoma.

Kenneth Webster et al (2000) ${ }^{11}$ in his study on Human Papillomavirus 16 E2 protein and E7 protein demonstrated that E2 and E7 induce apoptosis via a $\mathrm{p}^{53}$ - dependent pathway.

Horn LC et al (2001) ${ }^{12}$ studied about the prognostic value of $\mathrm{p}^{53}$ immunostaining in surgically treated and pathologically staged cervical cancer.

Wang HL and Lu DW (2004) $)^{13}$ conducted a study on detection of Human Papillomavirus DNA and expression of $\mathrm{p} 16, \mathrm{Rb}$ and $\mathrm{p}^{53}$ protein in 22 cases of small cell carcinomas of the uterine cervix. The $\mathrm{p}^{53}$ Protein was essentially undetectable in all cases.

Conner MG etal (2002) $)^{14}$ in his study on clinico pathologic and immunohistochemical analysis of 23 cases found the expression of $\mathrm{p}^{53}$ protein in 10 cases. $(43.5 \%)$.

Jo Milner (2006) ${ }^{15}$ of Yorkshire University $\mathrm{p}^{53}$ research group have shown that the $\mathrm{p}^{53}$ protein is activated in response to DNA damage and in response to agents that induce DNA damage.

In the present study 39 cases of squamous cell carcinoma were positive for $\mathrm{p}^{53}$ immuno expression out of 47 cases $(82.9 \%)$ one each of adenocarcinoma, adeno squamous carcinoma and smallcellcarcinoma was having positive $\mathrm{p}^{53}$ immuno expression. This was almost similar to that of K.Cooper et al (1993). [Table-2]

Table-2. Carcinoma cervix $-\mathbf{p}^{53}$ immuno reactivity

\begin{tabular}{|c|c|c|c|c|c|c|c|c|c|}
\hline \multirow{2}{*}{$\begin{array}{l}\text { S. } \\
\text { No }\end{array}$} & \multirow[t]{2}{*}{ Study } & \multicolumn{2}{|c|}{$\begin{array}{c}\text { Squamous cell } \\
\text { carcinoma }\end{array}$} & \multicolumn{2}{|c|}{$\begin{array}{c}\text { Adeno } \\
\text { carcinoma }\end{array}$} & \multicolumn{2}{|c|}{$\begin{array}{c}\text { Adeno. Sq } \\
\text { carcimoma }\end{array}$} & \multicolumn{2}{|c|}{$\begin{array}{l}\text { Small cell } \\
\text { carcinoma }\end{array}$} \\
\hline & & Positive & Neg & Positive & Neg & Positive & Neg & Positive & Neg \\
\hline 1. & $\begin{array}{l}\text { S. Bosari et al } \\
\text { (1993). } \mathrm{n}=19\end{array}$ & $\begin{array}{c}13(72 \%) \\
n=18\end{array}$ & 5 & $\begin{array}{c}1 \\
n=1\end{array}$ & - & - & - & - & - \\
\hline 2. & $\begin{array}{l}\text { A. Helland et al } \\
\text { (1993) } \mathrm{n}=92\end{array}$ & $\begin{array}{c}43(59 \%) \\
n=73\end{array}$ & 30 & $\begin{array}{c}4(44 \%) \\
n=9\end{array}$ & 5 & $\begin{array}{c}4(57 \%) \\
n=7\end{array}$ & 3 & $\begin{array}{c}3 \\
n=3\end{array}$ & - \\
\hline 3. & $\begin{array}{l}\text { K. cooper et al } \\
(1993) \cdot \mathrm{n}=30\end{array}$ & $\begin{array}{c}23(75.9 \%) \\
\mathrm{n}=29\end{array}$ & 6 & $\begin{array}{c}1 \\
n=1\end{array}$ & & & & & \\
\hline 4. & $\begin{array}{l}\text { R. Holm et al } \\
\text { (1993). } n=141\end{array}$ & $\begin{array}{c}23(22 \%) \\
\mathrm{n}=105\end{array}$ & 82 & $\begin{array}{l}2(6 \%) \\
\mathrm{n}=36\end{array}$ & 34 & & & & \\
\hline 5. & $\begin{array}{l}\text { Hunt \& Hale } \\
(1996) n=82\end{array}$ & $\begin{array}{c}5(22.7 \%) \\
\mathrm{n}=22\end{array}$ & 17 & $\begin{array}{c}5(14.3 \%) \\
\mathrm{n}=35\end{array}$ & 30 & $\begin{array}{l}4(16 \%) \\
n=25\end{array}$ & 21 & & \\
\hline 6. & $\begin{array}{l}\text { Conner MG et al } \\
(2002) n=23\end{array}$ & & & & & & & $\begin{array}{c}10 \\
\mathrm{n}=23\end{array}$ & 13 \\
\hline 7. & $\begin{array}{l}\text { Present Study } \\
\mathrm{n}=50\end{array}$ & $\begin{array}{c}39(82.9 \%) \\
\mathrm{n}=47\end{array}$ & 8 & $\begin{array}{c}1 \\
\mathrm{n}=1\end{array}$ & & $\begin{array}{c}1 \\
\mathrm{n}=1\end{array}$ & & $\begin{array}{c}1 \\
n=1\end{array}$ & \\
\hline
\end{tabular}

\section{CONCLUSION:}

Loss of $\mathrm{p}^{53}$ function was believed to play an important role in cervical carcinogenesis especially in squamous cell type.

\section{REFERENCES}

1. David M. Gershenson, William P, McGuire, Martin Gore, Michael A. Quinn and Gillian Thomas: Gynecologic Cancer - controversies in management. ELSEVIER CHURCHILL LIVINGSTONE. 2004; 4-9.

2. Vinaykumar, Abul K. Abbas, Nelson Fausto: Robbins and Cotran Pathologic basis of disease. 8th edition, SAUNDERS, NEW DELHI, INDIA. 2010; 1018-1024.

3. Hunt CR, Hale RJ, Buckley $\mathrm{CH}$, Hunt $\mathrm{J}: \mathrm{p}^{53}$ expression in carcinoma of the cervix. J Clin pathol.1996;49:971-974.

4. Tommasino.M., Accordi,R., C., Dong,W., 
Malanchi,I., Smet,A, and Zehbe, I: The role of TP53 in cervical carcinogenesis. Hum Mutat 2003; 21:307-312.

5. Atkin NB: Uterus: Carcinoma of the cervix. Atlas Genet Cytogenet Oncolhaematol. May 2000.

6. Bosari S. Roncalli M, Viale G, Bossi P, coggi G:P53immunoreactivity in inflammatory and neoplastic diseases of the uterine cervix. J Pathol 1993; 169: 425-430.

7. Helland A, Holm R, Kristensen G, Kaern J, Karisen F, Trope c et al:Genetic alterations of the Tp53 gene, P53 protein expression and HPV infection in primary cervical carcinomas. J pathol. 1993; 171: 105-114.

8. Cooper K, Herrington CS, Evans MF, Gatter KC and James O'D:P53 antigen in cervical condylomata, intraepithelial neoplasis and carcinoma: Relationship to HPV infection and integration: J Pathol.1993; 171:27-34.

9. Holm R, Skomedal H, Helland A, Kristensen G, Borresen AL, Nesland JM: Immunohistochemical analysis of $\mathrm{p} 53$ protein over expression in normal, premalignant and malignant tissues of the cervix uteri. J Pathol.1993; 169:21-26.

10. Howayda ABD EL ALL, Annie Rye, Pierre Duvillard:P53 immunohistochemical expression of Egyptian cervical carcinoma. Pathology \& oncology Research1999; 5(4): 280-284.

11. Webster K, Parish J, pandya M, Stern PL, Clarke AR and Gaston K:The human papilloma virus (HPV) 16 E2 Protein induces apoptosis in the absence of other HPV proteins and via a p53 dependent pathway. J Biol chemJanuary 7. 2000; 275(1): 87-94.

12. Horn Lc, Fischer U, Hanel C, Kuhn H, Raptis G and Bilek K: p53 in surgically treated and pathologically staged cervical cancer: correlation with local tumor progression, but not with lymphatic spread. Pathol Res Pract. 2001; 197 (9): 605-609.
13. Wang HL, LU DW: Detection of human papilloma virus DNA and expression of $\mathrm{p} 16, \mathrm{Rb}$ and $\mathrm{p} 53$ proteins in small cell carcinomas of the uterine cervix. Am J Surg pathol. Jul2004; 28 (7): 901908.

14. Conner MG, Richter H, Moran CA, Hanseed A, Albores -Saavedra J:Small cell carcinoma of the cervix-A clinicopathologic and immunohistochemical study of 23 cases. Ann Diagn Pathol; Dec2002; 6(6): 345-8.

15. Okorokov A., Sherman M.B., Plisson C., Grinkevich V., Sigmundsson K., Selivanova G., Milner J. and Orlova E.V. The structure of p53 tumour suppressor protein reveals the basis for its functional plasticity EMBO J. 2006; 25: 51915200 .

16. Rajaram S, Gupta G, Agarwal S, Goel N, Singh KC. High-risk human papillomavirus, tumor suppressor protein p53 and mitomycin-C in invasive squamous cell carcinoma cervix. Indian J Cancer. 2006; 43: 156-62.

17. Baxter E.W. and Milner J. p53 regulates LIF expression in human medulloblastoma cells. JNeurooncol.2010; 97: 373-82.

18. Kazufumi Suzuki and Hisahiro Matsubara. Recent Advances in p53 Research and Cancer TreatmentJournal of Biomedicine and Biotechnology. 2011;2011: Article ID 978312.

19. Amanda M Goh,Cynthia R Coffill, David P Lane. The role of mutant p53 in human cancer. J Pathol. 2011; 223(2): 116-26.

20. Soussi T. The TP53 Gene Network in a PostGenomic Era. Hum Mutat, 2014; 35: 641-642; Leroy, B., Ballinger, M. L., Baran-Marszak, F., Bond, G. L., Braithwaite, A., Concin, N.et al Recommended Guidelines for Validation, Quality Control, and Reporting of TP53 Variants in Clinical Practice. Cancer Res. 2017; 6: 1250-1260. 